\title{
Urgensi pendidikan karakter melalui pembelajaran PPKn
}

\author{
Bariyanti \\ ${ }^{a}$ MAN 1 Karanganyar \\ ${ }^{1}$ bariyanti02@gmail.com \\ * korespondensi penulis
}

\begin{abstract}
ABSTRAK
Pendidikan karakter merupakan upaya yang paling penting untuk membentuk kepribadian peserta didik. Melalui pendidikan karakter pula, dapat dilaksanakan penanaman niali-nilai moral pada peserta didik yang semakin lama semakin luntur menunjukkan hilangnya nilai-nilai kepribadian luhur bangsa Indonesia. Pendidikan karakter sangat erat kaitannya dengan Pendidikan Pancasila dan Kewarganegaraan. Melalui Pendidikan Pancasila dan Kewarganegaraan inilah diharapkan mampu mengimplemetasikan pendidikan karakter secara menyeluruh. Penelitian ini menggunakan metode deskriptif kualitatif yang menggunakan studi dokumen/ analisis dokumen yang terkait dengan pendidikan karakter dan pembelajaran PPKn. Analisis data menggunakan analisis kualitatif dan hasilnya berupa narasi kualitatif guna menemukan urgensi pendidikan karakter melalui pembelajaran PPKn. Hasil penelitian ini yakni strategi yang dapat dilaksanakan oleh guru dalam menerapkan pendidikan karakter melalui pembelajaran Pendidikan Pancasila dan Kewarganegaraan antara lain: (1) guru memahami dengan baik mengenai konsep dan indikator karakter yang hendak diinternalisasikan kepada peserta didik yang diwujudkan dalam silabus dan RPP (Rencana Pelaksanaan Pembelajaran), (2) guru mengembangkan pembelajaran aktif dengan menggunakan metode-metode pembelajaran untuk menanamkan nilai berpikir logis, kritis, kreatif dan inovatif, (3) guru sebagai teladan bagi siswa dalam menginternalisasikan nilai-nilai berbasis karakter.
\end{abstract}

Kata kunci: karakter; pendidikan karakter; ppkn; kewarganegaraan

\begin{abstract}
ABSTRACK
Character education is the most critical effort to shape the personality of students. Through character education, it can be carried out inculcating moral values in students who are increasingly fading, showing the loss of the Indonesian people's noble personality. Character education is closely related to Pancasila and Citizenship Education. Through Pancasila and Citizenship Education, it is hoped that it will implement comprehensive character education. This study uses a qualitative descriptive method that uses document study/document analysis related to character education and PPKn learning. The data analysis using qualitative research, and the result was a qualitative narrative to find character education's urgency through PPKn learning. This study's results are strategies that teachers can implement in implementing character education through Pancasila and Citizenship Education learning: (1) the teacher understands well the concepts and character indicators to be internalized to students, which are manifested in the syllabus and RPP (Implementation Plan). Learning), (2) the teacher develops active learning by using learning methods to instill the value of logical, critical, creative, and innovative thinking, (3) the teacher is a role model for students in internalizing character-based values.
\end{abstract}

Keywords: character education, civic education

Copyright $@ 2020$ Universitas Ahmad Dahlan

\section{PENDAHULUAN}

Pendidikan karakter merupakan isu yang sangat penting dalam dunia pendidikan dewasa ini, berkaitan dengan fenomena degradasi moral yang terjadi ditengah-tengah masyarakat maupun di lingkungan pemerintah yang semakin meningkat dan beragam. Kriminalitas, ketidak adilan, korupsi, kekerasan pada perempuan dan anak, pelangggaran HAM, menjadi bukti nyata bahwa telah terjadi krisis jati diri dan karakteristik pada bangsa Indonesia. Budi pekerti luhur, berkarakter emas. Kesantunan, dan keramahan yang dijunjung tinggi dan menjadi budaya bangsa Indonesia seakan-akan menjadi asing dan jarang ditemui di tengah-tengah masyarakat. Karakter masyarakat yang berkualitas perlu dibentuk dan dibina sejak usia dini, karena usia dini merupakan masa "emas" namun "kritis" bagi pembentukan karakter seseorang.

Munculnya gagasan program pendidikan karakter di Indonesia, dikarenakan selama ini proses pendidikan dirasa belum mampu membangun manusia Indonesia yang berkarakter. Hal ini terbukti dari beberapa kasus yang menyeret petinggi-petinggi negara yang merupakan lulusan dari lembaga pendidikan tinggi yang pandai dan mahir, berotak cerdas, namun tidak memiliki karakter kepribadian yang kuat bahkan cenderung 
amoral. Bahkan terdapat pula pakar-pakar bidang moral maupun bidang agama yang dalam kesehariannya mengajarkan tentang kebaikan namun perilakunya tidak sesuai dengan ilmu yang diajarkannya. Sejak kecil anak-anak diajarkan menghafal tentang bagusnya sikap jujur, berani, tanggungjawab, kerja keras, dan jahatnya kecurangan. Namun, nilai-nilai tersebut hanya diujikan sebatas pengetahuan di atas kelas dan belum terinternalisasi ke dalam diri siswa.

Pendidikan karakter bukanlah sebuah proses menghafal materi soal ujian, dan teknik-teknik menjawabnya. Pendidikan karakter memerlukan pembiasaan. Pembiasaan untuk berbuat baik, berlaku jujur, malu berbuat curang, malu bersikap malas, malu lingkungannya kotor dan lainnya. Salah satu alternatif yang dapat dilakukan dalam melaksanakan pendidikan karakter disekolah adalah mengoptimalkan pembelajaran materi Pendidikan Pancasila dan Kewarganegaraan (PPKn). Peran PPKn sangat strategis dalam mewujudkan pembentukan karakter siswa. PPKn merupakan sarana menimba pengetahuan dalam aspek kenegaraan (aspek kognitif), sebagai sarana perwujudan norma serta nilai moral untuk membentuk sikap (aspek afektif), yang berperan dalam mengendalikan perilaku (aspek psikomotorik) sehingga tercipta kepribadian manusia seutuhnya dan mampu menjadi warga negara yang baik (smart and good citizen).

\section{METODE}

Metode penelitian yang digunakan oleh peneliti adalah penelitian deskriptif kualitatif, karena menunjukkan adanya deskripsi terhadap urgensi pendidikan karakter melalui pembelajaran PPKn. Sutopo (2002, hal. 110) menyatakan bahwa "penelitian deskriptif merupakan tingkat kedua, yang merupakan pengembangan lanjut dari penelitian eksploratif. Peneliti mulai memprediksi variabel-variabel yang terlibat". Sehingga dapat disimpulkan bahwa metode deskriptif ialah metode yang memberikan gambaran secara jelas dan rinci tentang situasi yang terjadi saat sekarang berdasarkan fakta yang ada di lapangan.

Metode kualitatif yang digunakan adalah studi dokumen yang terkait dengan pendidikan karakter dan pembelajaran PPKn. Analisis data menggunakan analisis kualitatif dan hasilnya berupa narasi kualitatif guna menemukan urgensi pendidikan karakter melalui pembelajaran PPKn.

\section{HASIL DAN PEMBAHASAN}

\section{Konsep tentang pendidikan karakter}

Istilah karakter dihubungkan dengan istilah etika, ahlak, dan atau nilai dan berkaitan dengan kekuatan moral, berkonotasi "positif" bukan netral. Karakter adalah nilai-nilai yang melandasi perilaku manusia berdasarkan norma agama, kebudayaan, hukum/konstitusi, adat-istiadat, dan estetika. Pendidikan karakter adalah suatu sistem penanaman nilai-nilai perilaku (karakter) kepada warga sekolah yang meliputi pengetahuan, kesadaran atau kemauan, dan tindakan untuk melaksanakan nilai-nilai, baik terhadap Tuhan Yang Maha Esa (YME), diri sendiri, sesama, lingkungan, maupun kebangsaan sehingga menjadi insan kamil (Tim Pendidikan Karakter, 2010). Oleh karena itu Pendidikan Karakter secara lebih luas dapat diartikan sebagai pendidikan yang mengembangkan nilai budaya dan karakter bangsa pada diri peserta didik sehingga mereka memiliki nilai dan karakter sebagai karakter dirinya, menerapkan nilai-nilai tersebut dalam kehidupan dirinya sebagai anggota masyarakat, dan warga negara yang religius, nasionalis, produktif, dan kreatif.

Konsep tersebut harus disikapi secara serius oleh pemerintah dan masyarakat sebagai jawaban dari kondisi riil yang dihadapi bangsa Indonesia akhir-akhir ini yang ditandai dengan maraknya tindakan kriminalitas, memudarnya nasionalisme, munculnya rasisme, memudarnya toleransi beragama serta hilangnya religiusitas dimasyarakat, agar nilai-nilai budaya bangsa yang telah memudar tersebut dapat kembali membudaya ditengah-tengah masyarakat. Salah satu upaya yang dapat segera dilakukan adalah memperbaiki kurikulum dalam sistem pendidikan nasional yang mengarahkan pada pendidikan karakter secara nyata. Membangun karakter bangsa sangat tergantung kepada bangsa itu sendiri. Bila bangsa tersebut memberikan perhatian yang cukup untuk membangun karakter maka akan terciptalah bangsa yang berkarakter. Pembangunan karakter yang paling efektif dan berkesinambungan yakni melalui pendidikan, yang kita kenal hari ini dengan istilah pendidikan karakter. Pendidikan merupakan media paling sistematis dan efektif untuk memperkuat character building (Naim, 2012, hal. 24).

Di dalam undang-undang Nomor 20 tahun 2003 tentang Sistem Pendidikan Nasional sebenarnya pendidikan karakter menempati posisi yang penting, hal ini dapat kita lihat dari tujuan pendidikan nasional yang menyatakan bahwa: "Pendidikan nasional berfungsi mengembangkan kemampuan dan membentuk watak serta 
peradaban bangsa yang bermartabat dalam rangka mencerdaskan kehidupan bangsa, bertujuan untuk berkembangnya potensi peserta didik agar menjadi manusia yang beriman dan bertakwa kepada Tuhan Yang Maha Esa, berakhlak mulia, sehat, berilmu, cakap, kreatif, mandiri, dan menjadi warga negara yang demokratis serta bertanggung jawab."

\section{Strategi pendidikan karakter melalui pembelajaran PPKn}

Pendidikan karakter tidak bisa dijadikan terobosan apalagi bersifat instan atau seketika. Pembentukan karakter yang mantap tidak muncul hanya dilakukan di sekolah. Namun, demikian pendidikan karakter dapat dilakukan di sekolah dengan mensosialisasikan dan melakukan karakter utama seperti solidaritas, toleransi, penghargaan, kejujuran, tanggung jawab, dalam masyarakat yang multikultural yang mencintai Identitas Nasional yang diperoleh dari pemahaman dan komitmenya pada ide-ide demokrasi seperti martabat manusia, keadilan dan persamaan. Sebagai anggota masyarakat siswa berkembang baik berdasar etnisitas dan identitas nasional memiliki perspektif global dan mengidentifikasi sebagai warganegara yang baik dan merasa jadi komunitas dunia.

Menurut Lickona (2009) terdapat 11 prinsip agar pendidikan karakter dapat berjalan efektif sebagai berikut: (1) kembangkan nilai-nilai etika inti dan nilai-nilai kinerja pendukungnya sebagai pondasi karakter yang baik, (2) definisikan 'karakter' secara komprehensif yang mencakup pikiran, perasaan, dan perilaku, (3) gunakan pendekatan yang komprehensif, disengaja, dan proaktif dalam pengembangan karakter, (4) ciptakan komunitas sekolah yang penuh perhatian, (5) beri siswa kesempatan untuk melakukan tindakan moral, (6) buat kurikulum akademik yang bermakna dan menantang yang menghormati semua peserta didik, mengembangkan karakter, dan membantu siswa untuk berhasil, (7) usahakan mendorong motivasi diri siswa, (8) libatkan staf sekolah sebagai komunitas pembelajaran dan moral untuk berbagi tanggung jawab dalam pendidikan karakter dan untuk mematuhi nilai-nilai inti yang sama dalam membimbing pendidikan siswa, (9) tumbuhkan kebersamaan dalam kepemimpinan moral dan dukungan jangka panjang bagi inisiatif pendidikan karakter, (10) libatkan keluarga dan anggota masyarakat sebagai mitra dalam upaya pembangunan karakter, (11) evaluasi karakter sekolah, fungsi staf sekolah sebagai pendidik karakter, dan sejauh mana siswa memanifestasikan karakter yang baik.
Untuk membangun karakter menurut Soedarsono (2009, hal. 37) tidak mungkin hanya dengan diajarkan akan tetapi harus melalui empat koridor yang dijalankan sepanjang berlangsungnya kurikulum, yaitu:

1. Menginternalisasikan nilai moral dari luar yang dipadukan dengan nilai-nilai dari dalam;

2. Memberitahukan apa yang boleh dan tidak boleh dipahami sehingga peserta didik dengan senang hati akan melakukan yang boleh dan meninggalkan yang tidak boleh;

3. Membentuk kebiasaan yang harus selalu dipantau; dan,

4. Mendapat suri teladan dari guru secara berkesinambungan dan berkelanjutan.

Upaya tersebut dapat dilakukan melalui PPKn. Melalui PPKn selain substansi dari materimateri pembelajaran/kognitif, guru juga diharapkan mampu mengembangkan pembelajaran menuju ke ranah afektif serta psikomotor. Guru tidak hanya sebagai orang yang melakukan transfer of knowlegde tetapi guru sebagai model yang pantas untuk ditiru siswa dan sebagai orang yang mampu melakukan transfer of value.

Mata pelajaran Pendidikan Pancasila dan Kewarganegaraan (PPKn) merupakan mata pelajaran yang memfokuskan pada pembentukan warga negara yang memahami dan mampu melaksanakan hak dan kewajibannya untuk menjadi warga negara yang berkarakter, cerdas, dan terampil yang diamanatkan oleh Pancasila dan UUD 1945. Tiga kompetensi yang harus diperhatikan guru dalam PPKn yang mampu mengotrol kebijakan pemerintah, yaitu (1) peserta didik mampu berpikir kritis, rasional dan kreatif, dalam merespon isu-isu Kewarganegaraan, (2) peserta didik mampu berpartisipasi secara cerdas dan bertanggung jawab dalam kegiatan bermasyarakat, berbangsa dan bernegara, dan (3) peserta didik mampu membentuk diri berdasakan kepada karakter-karakter positif masyarakat Indonesia dan masyarakat dunia yang demokratis.

Sejalan dengan tujuan PPKn, aspek-aspek kompetensi yang hendak dikembangkan dalam Pembelajaran PPKn mencakup pengetahuan kewarganegaraan (civic knowledge) yang menyangkut berbagai teori dan konsep politik, hukum, dan pendidikan moral (penanaman nilai Pancasila), keterampilan kewarganegaraan (civic sklils), meliputi keterampilan intelektual (intelectual skills), keterampilan berpartisipasi (participa-tory skills) dalam kehidupan berbangsa dan bernegara. Karakter kewarganegaraan (civic disposition) ini merupakan dimensi yang paling substansif dan essensial dalam pembelajaran 
PPKn, karena dengan menguasai pengetahuan kewarganegaraan dan keterampilan negara yang baik. Misalnya, religius, jujur, adil, demokratis, menghargai perbedaan, menghormati hukum, menghormati HAM, memiliki semangat kebangsaan yang kuat, rela berkorban dan sebagainya.

Untuk mewujudkan pendidikan PPKn sebagai bagian dari pendidikan karakter yang mengandung moral, nilai, demokrasi serta Pancasila, maka ada beberapa hal yang perlu dilakukan guru PPKn, yakni sebagai berikut:

Dalam pembelajaran PPKn sebaiknya dilaku kan dengan pendekatan komprehensif, baik komprehensif dalam isi, metode, maupun dalam keseluruhan proses pendidikan. Isi pendidikan PPKn hendaknya meliputi semua permasalahan yang berkaitan dengan pilihan nilai pribadi sampai nilai-nilai etika yang bersifat umum. Selain itu, guru PPKn juga perlu memahami dengan baik mengenai konsep dan indikator karakter yang hendak diinternalisasikan kepada peserta didik supaya guru PPKn dapat membuat silabus dan RPP dengan baik sehingga dapat melaksanakan pembelajaran secara efektif.

Metode pembelajaran PPKn yang digunakan oleh guru PPKn, harus mengembangkan pembelajaran aktif dengan menggunakan banyak metode belajar seperti penanaman nilai melalui studi pustaka, klarifikasi nilai melalui mengamati/ mengobservasi, analisis nilai melalui pemecahan masalah/kasus, maupun diskusi kelas untuk menanamkan nilai berpikir logis, kritis, kreatif dan inovatif.

Guru PPKn hendaknya menjadi model atau contoh bagi peserta didik sebagai guru yang berkarakter. Jadi dalam setiap sikap dan tindakan guru PPKn harus menggambarkan karakter yang diinternalisasikan kepada peserta didiknya.

Untuk mewujudkan PPKn sebagai bagian dari pendidikan karakter maka harus menciptakan kultur sekolah yang kondusif bagi pengembangan karakter peserta didik. Sehingga, kultur sekolah yang berupa norma-norma, nilai-nilai, sikap, harapan-harapan, dan tradisi yang ada di sekolah yang telah diwariskan dan dipegang bersama yang mempengaruhi pola pikir, sikap, dan pola tindakan seluruh warga sekolah. Karena kultur sekolah yang positif dan sehat akan kewarganegaraan akan membentuk watak/karakter, sikap dan kebiasaan hidup seharihari yang mencerminkan warga berdampak pada motivasi, prestasi, produktivitas, kepuasan serta kesuksesan siswa dan guru.

\section{KESIMPULAN}

Upaya pembentukan karakter bangsa bukanlah upaya yang mudah dan dengan cepat dapat dilakukan. Tetapi dengan upaya yang sungguh-sungguh dan meliputi berbagai aspek serta dibutuhkan kerjasama antar komponen masyarakat. Pendidikan Pancasila dan Kewarganegaraan adalah salah satu upaya serius yang dilakukan pemerintah melalui penyusunan kurikulumnya yang menitikberatkan tidak hanya pada kecerdasan intelektual juga namun lebih menekankan pada upaya pembentukan karakter siswa (character building). Dengan terwujudnya pembelajaran PPKn yang terpadu dan menyeluruh maka penyelenggaraan pendidikan karakter yang dilakukan sekolah dapat berhasil dan membentuk bangsa Indonesia yang berbudaya dan beradab. Satuan Pendidikan terutama guru hendaknya bersungguh-sungguh dalam mewujudkan tujuan pendidikan nasional agar pendidikan karakter yang terpadu dalam PPKn dapat memberikan hasil yang memuaskan bagi pembentukan budaya perilaku bangsa Indonesia.

\section{DAFTAR PUSTAKA}

Lickona, T. (2009). Educating for character: How our schools can teach respect and responsibility. Bantam Books.

Naim, N. (2012). Character Building. Ar-Ruzz Media.

Soedarsono, S. (2009). Karakter Mengantar Chicago Bangsa Dari Gelap Menuju Terang. Elex Media Komputindo.

Sutopo. (2002). Metodologi penelitian kualitatif. UNS Press.

Tim Pendidikan Karakter. (2010). Pendidikan karakter di SMP. Kementerian Pendidikan Nasional. 